\title{
EXPERIMENTAL INVESTIGATION ON THE PROPERTIES OF CEMENT CONCRETE PARTIALY REPLACED BY SILCA FUME AND FLY ASH
}

\author{
Salim Khoso* \\ Quaid-e-Awam University College of Engineering, Sciences \& Technology (QUCEST), \\ Larkana, Sindh, Pakistan \\ Jam Shahzaib Khan, \\ Quaid-e-Awam University College of Engineering, Sciences \& Technology (QUCEST), \\ Larkana, Sindh, Pakistan \\ Abdul Aziz Ansari, \\ Mehran University of Engineering \& Technology SZAB campus, Khairpur Mir's, Sindh, \\ Pakistan \\ Zahid Hussain Khaskheli, \\ Quaid-e-Awam University College of Engineering, Sciences \& Technology (QUCEST), \\ Larkana, Sindh, Pakistan
}

The aim of this research work is to investigate the optimum replacement of cement by silica fume and fly ash and to calculate the compressive strength of concrete. The cement has been replaced by fly ash and Silica fume varying in different percentage like 0\%, 10\%, 20\%, 30\%, 40\% and 50\% by weight of cement. Concrete specimens of ratios 1:2:4 and 1:1.5:3 were prepared, cured, tested and compared in term of compressive and split tensile strength with the traditional concrete. Tests were conducted to calculate the mechanical properties for the concrete ranging from 7, 14 and 28 days curing both for compressive and split tensile strength. It has been observed that the compressive strength increases when cement is replaced $10 \%$ by Silica fume and Fly ash. However, the compressive strength is gradually reduced when the cement replaced more than $10 \%$. The effect of Silica fume and Fly ash on various other concrete properties has also been investigated in this paper. It has also been observed that the use of Silica fume and Fly ash not only improve the various properties of concrete but could also be economical in cost of construction.

Key words: Silica Fume, Fly Ash, Concrete, Replacement, Compressive strength

\section{INTRODUCTION}

Ordinary Portland cement (OPC) concrete is one of the most abundantly used building materials in the modern era, which is found largely acceptable all over the world during past more than hundred years. Many researchers are engaged in replacing cement partially by many versatile materials. Similarly the experimental work in this paper investigates the properties of cement concrete replaced partially by Silica fume and Fly ash which was tested as a substitute to conventional concrete. Silica fume is a metallic and non hazardous byproduct of producing silicon metal or ferrosilicon alloys which includes pozzolanic properties like cement. In this way the Pozzolans materials when are mixed in concrete, chemically starts to react with Calcuim Hydroxide i.e. lime at normal temperature which is produced during the hydration of Cement. Whereas, Fly ash is also used as an additional cementitious material in manufacturing of portland cement concrete. Fly ash when used in combination with OPC contributes to the properties of the hardened concrete through hydration process or pozzolanic action or vice versa [01]. No doubt manufacturing of cement consumes large amount of energy. It is believed that about 1 ton of Carbon dioxide is released into the atmosphere during the production of 1 cement ton [02]. Therefore partial replacement of OPC with byproducts of minerals like fly ash and silica fume can considerably lessen emission of $\mathrm{CO} 2$ [03]. Fly ash has been found a good material in improving the workability and contributing in strength development and 
therefore considered to be a valuable cementitious component of concrete [04]. The benefits of using Fly ash and silica fume both in normal and high strength concrete reduces to generate heat in order to gain improved durability properties [5]. However, Fly ash also has high fineness, which helps in decreasing porosity and pore size ultimately increases the compressive strength [06] The chemical composition of all three materials used including Portland cement, Silica fume and fly ash is given in Table 1.

Table 1: Chemical composition of all three materials used

\begin{tabular}{|c|c|c|c|}
\hline Chemical Composition & Portland Cement & Silica Fume & Fly Ash \\
\hline $\mathrm{CaO}$ & 62.8 & 0.58 & 6.95 \\
\hline $\mathrm{SiO}_{2}$ & 21.5 & 92.48 & 46.87 \\
\hline $\mathrm{Al}_{2} \mathrm{O}_{3}$ & 6.02 & 0.64 & 26.54 \\
\hline $\mathrm{Fe}_{2} \mathrm{O}_{3}$ & 3.42 & 1.56 & 11.32 \\
\hline $\mathrm{MgO}$ & 0.89 & 0.39 & 2.18 \\
\hline $\mathrm{Na}_{2} \mathrm{O}$ & 0.08 & 0.45 & 1.08 \\
\hline $\mathrm{SO}_{3}$ & 3.41 & 0.16 & 1.79 \\
\hline $\mathrm{K}_{2} \mathrm{O}$ & 0.64 & 0.89 & 3.05 \\
\hline Loss on Ignition (\%) & 1.24 & 2.85 & 0.22 \\
\hline
\end{tabular}

\section{EXPERIMENTAL WORK}

The experimental work for this research was aimed to investigate the compressive strength and split tensile strength of concrete replaced partially by Silica fume and Fly ash. Cement was replaced with different percentage levels in this experimental work in order to quantify the effects of various levels of Silica fume and fly ash in cement concrete and their contribution in the compressive and split tensile strength of concrete specimens. Around 200 concrete specimens were cast and cured at different periods with different aggregate ratios.

\section{MATERIALS USED \\ Cement}

ASTM Type-1 Ordinary Portland Cement conforming to ASTM C-150 [07] under the brand name Lucky from Lucky cement factory, Karachi, Pakistan, was used as a binding material for all mix proportions.

\section{Fine Aggregate}

Clean natural sand available locally which was passing and retaining through $4.75 \mathrm{~mm}$ and $0.015 \mathrm{~mm}$ sieve respectively was used for this experimental work.

\section{Coarse Aggregate}

Locally available coarse aggregate passing from sieve no. 4 with maximum size of $19 \mathrm{~mm}$ and having water absorption $2 \%$ was used for all the specimens.

\section{Silica Fume and Fly ash}

Silica fume and Fly ash both are abundantly produced in the country. The Silca fume and Fly ash used for this experimental investigation were brought from industries in major city of Pakistan i.e. Karachi.

\section{Water}

Fresh tap water available in the engineering college was used. It was tested before using which gave average $\mathrm{pH}$ value of 7.2.

\section{METHODOLOGY OF THE EXPERIMENTAL WORK}

All the materials mentioned above were collected and brought to the structural laboratory. Overall 200 cement concrete specimens including both cubes and cylinders were cast. The specimens cast include plain cement concrete specimens as well as samples made with silica fume and fly ash. Two different ratios 1:2:4 and 1:1.5:3 were planned for Cement concrete specimens. Cement replacement was in the ranges $10 \%$, $20 \%, 30 \%, 40 \%$ and $50 \%$ by weight of total cement used. Slump cone test for fresh concrete was conducted to determine the workability. The specimens cast were kept in water for curing period of 7,14 , and 28 days. The mould size was $150 \times 150 \mathrm{~mm}$ for cubes and the cylinder size was with $150 \mathrm{~mm}$ dia and depth equal to $300 \mathrm{~mm}$. After curing specimens were tested for compressive and split tensile strength and the results were 
compared with the traditional cement concrete [08 - 15].

\section{RESULTS AND DISCUSSIONS}

\section{Workability Test}

Workability test for all mix designs with different percentage of cement replacement and concrete specimens made with $1: 2: 4$ and $1: 1.5: 3$ ratios was done. Slump cone having dimensions as illustrated in Figure 1 was used for all the concrete mix designs prepared. Slump cone test results of all concrete mix designs with varying proportions are presented in Table 2.

Table 2: Workability test results of concrete mixes with varying proportions

\begin{tabular}{|c|c|c|c|c|c|}
\hline Cement Replacement \% & W/c Ratio & $\begin{array}{c}\text { Mix Design } \\
\text { Ratio }\end{array}$ & Slump (in.) & $\begin{array}{c}\text { Mix Design } \\
\text { Ratio }\end{array}$ & Slump (in.) \\
\hline 0 & 0.5 & $1: 2: 4$ & 2.36 & $1: 1.5: 3$ & 2.61 \\
\hline 10 & 0.5 & $1: 2: 4$ & 1.61 & $1: 1.5: 3$ & 1.77 \\
\hline 20 & 0.5 & $1: 2: 4$ & 1.06 & $1: 1.5: 3$ & 1.33 \\
\hline 30 & 0.5 & $1: 2: 4$ & 0.70 & $1: 1.5: 3$ & 0.86 \\
\hline 40 & 0.5 & $1: 2: 4$ & 0.31 & $1: 1.5: 3$ & 0.51 \\
\hline 50 & 0.5 & $1: 2: 4$ & 0.18 & $1: 1.5: 3$ & 0.3 \\
\hline
\end{tabular}

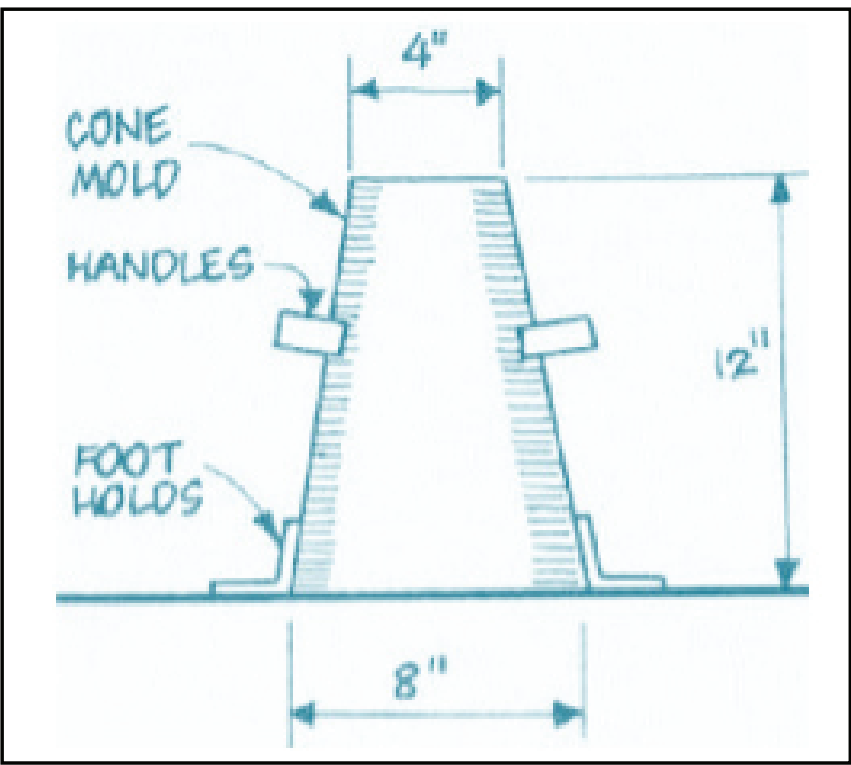

Figure 1: Slump cone dimensions in inches

Test results of both compressive and tensile strength for specimens cast with different ratios and after the curing period of 3,7 , and 28 days were determined and are presented in Table 3 and 4 respectively as well as in Figures 2 to 7 . Compressive and tensile strength of concrete containing different percentage of silica fume and fly ash was investigated. Traditional concrete strength was compared with the strength of concrete mixes containing $10 \%, 20 \%, 30 \%$, $40 \%$ and $50 \%$ of silica fume and fly ash.

\section{Compressive Strength}

Number of concrete specimens cast was tested on Universal testing machine (UTM) in the struc- tural laboratory. Compressive test results revealed that the maximum strength was obtained when the cement was replaced at $10 \%$ by Silica fume and Fly ash. The maximum strength obtained for both $1: 2: 4$ and 1:1.5:3 is at various curing stages is given in Table 3 . The results show that the compressive strength was decreased as the ratio of Silica fume and Fly ash was increased in concrete. The maximum compressive strength obtained was at 25 days curing period i.e. $34.49 \mathrm{Mpa}$ 
Table 3: Compressive strength test results of Cubes and Cylinders

\begin{tabular}{|c|c|c|c|}
\hline $\begin{array}{l}\text { Percentage of Silica } \\
\text { Fume + Fly Ash }\end{array}$ & 7 Days Strength $\quad(\mathrm{Mpa})$ & 14 Days Strength (Mpa) & 28 Days Strength (Mpa) \\
\hline \multicolumn{4}{|c|}{ Compressive strength of cubes made with 1:2:4 cement Ratio } \\
\hline 0 & 16.09 & 18.16 & 28.06 \\
\hline 10 & 18.44 & 21.18 & 34.49 \\
\hline 20 & 10.02 & 12.27 & 16.54 \\
\hline 30 & 5.38 & 6.85 & 8.37 \\
\hline 40 & 2.98 & 3.89 & 4.81 \\
\hline 50 & 1.82 & 2.33 & 2.59 \\
\hline \multicolumn{4}{|c|}{ Compressive strength of cubes made with 1:1.5:3 cement Ratio } \\
\hline 0 & 18.51 & 20.75 & 34.75 \\
\hline 10 & 21.48 & 23.3 & 37.74 \\
\hline 20 & 15.34 & 18.32 & 20.62 \\
\hline 30 & 8.71 & 9.61 & 14.88 \\
\hline 40 & 6.02 & 7.2 & 8.36 \\
\hline 50 & 3.39 & 3.75 & 4.9 \\
\hline \multicolumn{4}{|c|}{ Compressive strength of cylinders made with 1:2:4 cement Ratio } \\
\hline 0 & 12.17 & 14.27 & 22.11 \\
\hline 10 & 14.8 & 16.97 & 28.54 \\
\hline 20 & 7.25 & 10.11 & 12.89 \\
\hline 30 & 3.51 & 5.02 & 6.56 \\
\hline 40 & 2.75 & 3.2 & 3.84 \\
\hline 50 & 1.66 & 1.95 & 2.12 \\
\hline \multicolumn{4}{|c|}{ Compressive strength of cylinders made with 1:1.5:3 cement Ratio } \\
\hline 0 & 15.44 & 16.59 & 27.74 \\
\hline 10 & 17.04 & 18.86 & 29.35 \\
\hline 20 & 11.58 & 13.89 & 16.38 \\
\hline 30 & 6.52 & 7.06 & 12.22 \\
\hline 40 & 3.93 & 5.06 & 6.09 \\
\hline 50 & 2.65 & 2.99 & 4.35 \\
\hline
\end{tabular}

Table 4: Tensile strength test results of Cylinders

\begin{tabular}{|c|c|c|c|}
\hline $\begin{array}{c}\text { Percentage of Silica Fume } \\
+ \text { Fly Ash }\end{array}$ & 7 Days Strength $\quad(M p a)$ & 14 Days Strength (Mpa) & 28 Days Strength (Mpa) \\
\hline \multicolumn{4}{|c|}{ Tensile strength of cylinders made with 1:2:4 cement Ratio } \\
\hline 0 & 4.37 & 4.80 & 7.28 \\
\hline 10 & 5.11 & 5.62 & 8.03 \\
\hline 20 & 2.72 & 3.56 & 3.87 \\
\hline 30 & 1.43 & 1.82 & 2.26 \\
\hline 40 & 0.88 & 1.22 & 1.12 \\
\hline 50 & 0.69 & 0.80 & 0.92 \\
\hline \multicolumn{4}{|c|}{ Tensile strength of cylinders made with 1:1.5:3 cement Ratio } \\
\hline 0 & 5.72 & 6.62 & 8.56 \\
\hline 10 & 6.89 & 7.62 & 9.12 \\
\hline 20 & 3.89 & 4.68 & 4.64 \\
\hline 30 & 2.51 & 3.19 & 3.34 \\
\hline 40 & 1.57 & 2.01 & 2.02 \\
\hline 50 & 0.81 & 1.18 & 1.44 \\
\hline
\end{tabular}




\section{Tensile Strength}

To check the tensile strength of cement concrete made with supplementary materials like Silica fume and Fly ash, cylinder specimens of size $150 \mathrm{~mm}$ dia and height of $300 \mathrm{~mm}$ were cast. After completion of different curing periods the cylinders were tested on UTM. Test results re-

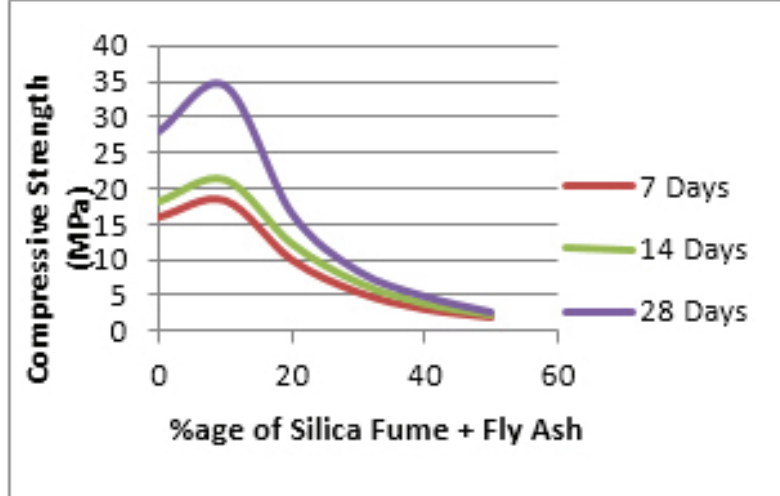

Figure 2: Strength of Cubes made with 1:2:4 ratio

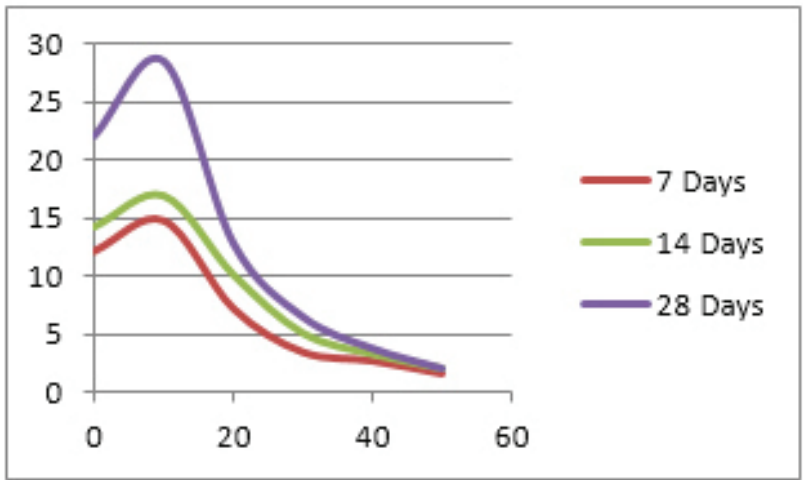

Figure 4: Strength of Cylinders made with 1:2:4 ratio

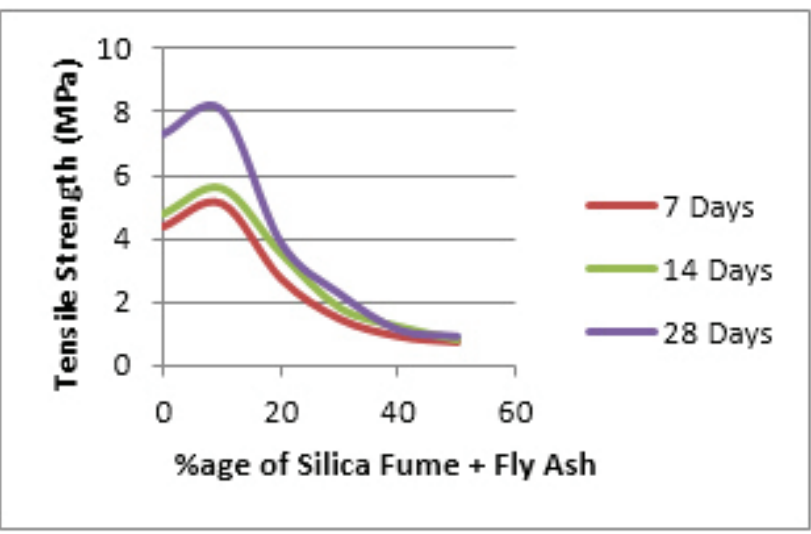

Figure:6 Strength of cylinders made with 1:2:4 ratio

\section{CONCLUSION}

It is investigated from the experimental study that the Silica fume and Fly ash is a better replacement for cement. The strength obtained by using both these materials is higher than the traditional vealed that the strength was increased when cement was replaced by $10 \%$ with Silica fume and Fly ash. Gradual decrease in strength was observed when the percentage of Silica fume and Fly ash was increased in cement concrete. The results of tensile strength obtained are presented in Table 4.

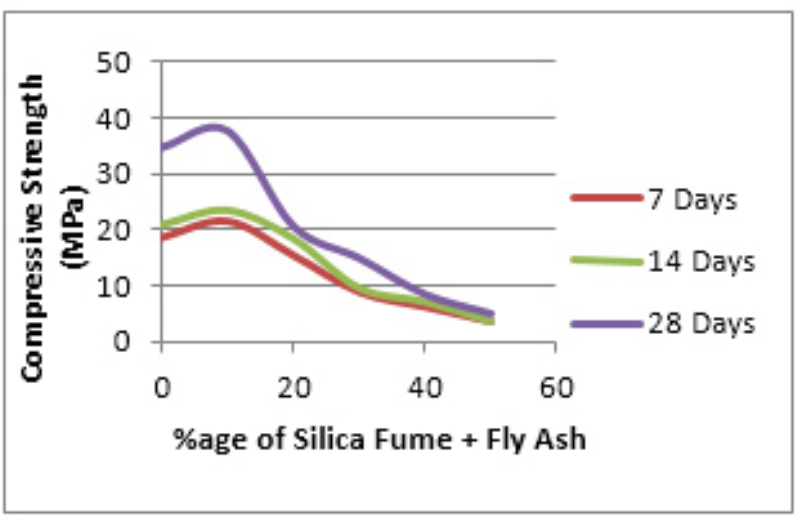

Figure:3 Strength of Cubes made with 1:1.5:3 ratio

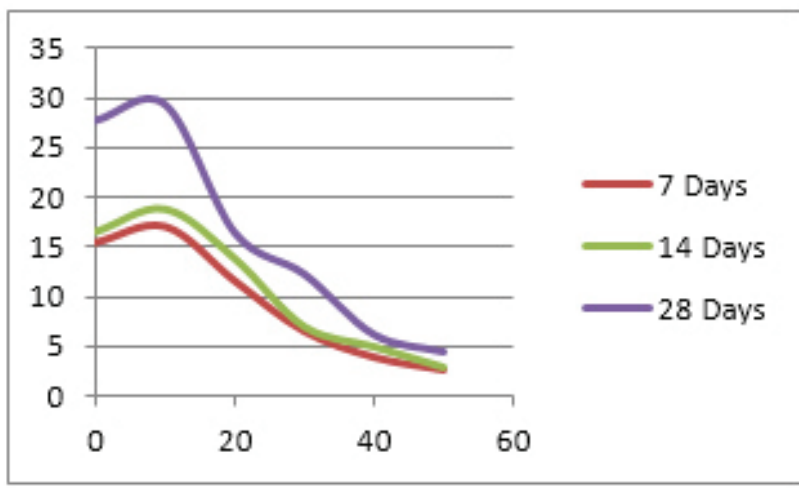

Figure 5: Strength of Cylinders made with 1:1.5:3

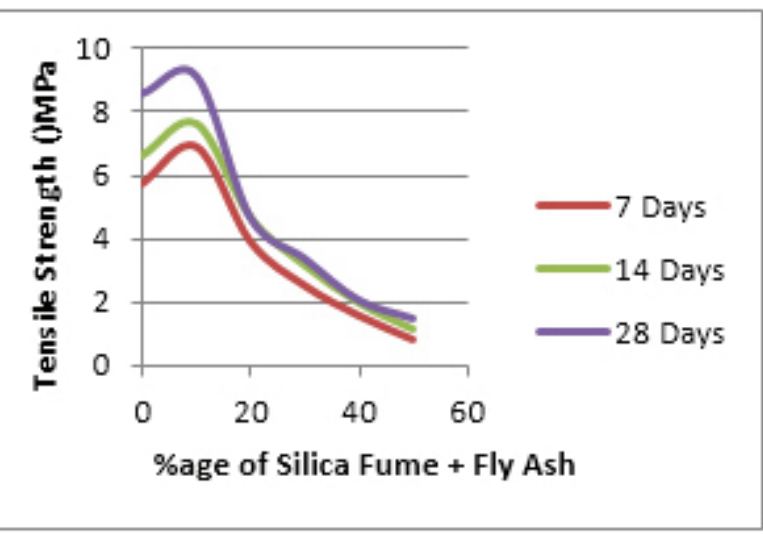

Figure:7 Strength of Cylinders made with 1:1.5:3

cement concrete. After performing this experimental work and investigations the following conclusions has been revealed;

1. Replacement of Portland cement with $10 \%$ of Silica fume and Fly ash gives high compressive strength. 
2. Decrease in the compressive strength of concrete is observed when there is increase in the percentage of Silica fume and fly ash in concrete.

3. Tensile strength of concrete is also increased with the addition of both Silica fume and fly ash in the cement concrete.

4. Workability of cement concrete decreased due to the availability of Silica fume.

5. The research work shows that both Silica fume and fly ash used together in concrete can be an innovative idea as supplementary cementitious material for construction.

\section{ACKNOWLEDGMENT}

The details of the experimental study shown in this paper were conducted in the Structural Engineering Laboratory, Department of Civil Engineering, Quaid-e-Awam University College of Engineering, Science and Technology, Nawabshah. The authors are highly thankful to the students and the laboratory staff for their cooperation in this regard.

\section{REFERENCES}

1) Michael Thomas, Ph.D., P.Eng., Professor of Civil Engineering, "Optimizing the Use of Fly Ash in Concrete" University of New Brunswick

2) Min-Hong, Zhang., Marcia, C. Blanchette., and V, M. Malhotra., Leachability of Trace Metal Elements from Fly Ash Concrete: Results form Column-Leaching and Batch Leaching Tests, $\mathrm{ACl}$ Materials Journal, 2001, 98 (2), pp.126-136.

3) Ozkan, Sengul., and Mehmet, Ali. Tasdemir., 2009, "Compressive Strength and Rapid Chloride Permeability of Concretes with Ground Fly Ash and Slag", Journal of Materials in Civil Engineering, 2009, 21 (9), pp.494-501.

4) Elkhadiri, I., Diouri, A., Boukhari.A., Aride, J., Puertas, F., Mechanical behaviour of various mortars made by combined fly ash and limestone in Moroccan Portland cement, Cement and Concrete Research, 2002, 32, pp.1597-1603.

5) Poon, C. S., Lam, L., Wong, Y. L., "A Study on High Strength Concrete Prepared with Large Volumes of low Calcium Fly Ash", Cement and Concrete Research, 2002, 30 (3), pp. 447-455.

6) Md. Moinul Islam, Md. Saiful Islam, "Strength Behaviour of Mortar Using Fly ash as Partial Replacement of Cement" Concrete Research Letters, Vol. 1(3) 2010, pp. 98-106

7) ASTM C 190-85, Standard Test Method for Tensile Strength of Hydraulic Cement Mortars, Annual Book of ASTM Standards, 1988, (Vol.
4.01-Cements, Lime, Gypsum), Easton, USA

8) Vishal S. Ghutke, Pranita S. Bhandari, "Influence of silica fume on concrete", IOSR Journal of Mechanical and Civil Engineering (IOSRJMCE) e-ISSN: 2278-1684, p-ISSN: 2320334X, PP 44-47, 2014

9) Jayeshkumar Pitroda, L.B. Zala, F.S. Umrigar, "Experimental Investigations on Partial Replacement of Cement with Fly ash in design mix concrete", International Journal of Advanced Engineering Technology, IJAET Vol.3 Issue 4 Oct.-Dec., 2012, pp.126-129.

10) Salim Khoso, Farhan $H$. wagan, Jam S. Khan, N.K. Bhatti, A.A. Ansari, "Qualitative Analysis of Baked Clay Bricks available in Larkana region, Pakistan" Journal of Architecture Civil Engineering Environment ACEE, Poland June, 2014, Vol. 7, No. 2, June 2014, pp. 41-50.

11) Muhammad Tayyab Naqash, Khalid Mahmood, Salim Khoso "An Overview on the Seismic Design of Braced Frames" American Journal of Civil Engineering, Vol. 2, No. 2, 30th March, 2014, pp. 41-47.

12) Salim Khoso, Abdul Aziz Ansari, Farhan $\mathrm{H}$. Wagan, "Investigative Construction of Buildings using Baked Clay Post-reinforced Beam Panels" Journal of Architecture Civil Engineering Poland December, 2014, Vol. 7, No. 4, December 2014, pp. 57-66. ISSN: 1899-0142.

13) A.A. Ansari, Sajjad. A. Mangi, Salim Khoso, Kanya L. Khatri, Ghulam S. Solangi, "Latest Developments in the Structural Material Consisting of Reinforced Baked Clay" in proceedings of 7th International Civil Engineering Congress (ICEC2015), Sustainable Developments through Advancements in Civil Engineering, June 12-13, 2015, Karachi, Pakistan, pp. 33-43.

14) Salim Khoso, Farhan Hussain Wagan, Abdul Hanan Tunio, Abdul Aziz Ansari, "An Overview on Emerging Water Scarcity in Pakistan; its causes, Impacts and remedial measures", Journal of Applied Engineering Science, Serbia, ISSN 1451-4117, March, 2015, Vol.13, No.1, pp $35-44$.

15) Salim Khoso, A.A. Ansari, Jam S. Khan, Farhan H. Wagan, "Experimental Study on Recycled Concrete using Dismantled Road Aggregate and Baggase Ash" in proceedings of 7th International Civil Engineering Congress (ICEC2015), Sustainable Developments through Advancements in Civil Engineering, June 12-13, 2015, Karachi, Pakistan, pp. 54-61.

Paper sent to revision: 11.06.2016.

Paper ready for publication: 15.07.2016. 